\title{
Experimental Evaluation of the Performance of Fresh Nano Zeolite as an Oil Well Cement Additive
}

\author{
Eric Broni-Bediako, Fulgence Maal-Ire Naatu \\ Department of Petroleum and Natural Gas Engineering, School of Petroleum Studies, University of Mines and Technology (UMaT), Tarkwa, \\ Ghana
}

\author{
Email address: \\ ebroni-bediako@umat.edu.gh (E. Broni-Bediako), fnaatu8@gmail.com (F. Maal-Ire N.)
}

\section{To cite this article:}

Eric Broni-Bediako, Fulgence Maal-Ire Naatu. Experimental Evaluation of the Performance of Fresh Nano Zeolite as an Oil Well Cement Additive. Petroleum Science and Engineering. Vol. 5, No. 1, 2021, pp. 1-12. doi: 10.11648/j.pse.20210501.11

Received: January 24, 2021; Accepted: February 6, 2021; Published: February 10, 2021

\begin{abstract}
Cementing oil and gas wells require materials that, not only meet performance standards but also fairly different from those encountered in conventional processes. The search for alternative materials for cementing oil wells has increased worldwide. It is desirable that these alternative materials make cement sheath stronger, durable, flexible, cost-effective and more resistant to shocks. This research aimed at evaluating the performance of fresh nano zeolite as an additive for shallow oil well cementing operations. Laboratory tests were conducted on a base cement slurry mixed with different concentrations of fresh nano zeolite from $1 \%$ bwoc to $3 \%$ bwoc at a Bottomhole Circulating Temperature (BHCT) of $80^{\circ} \mathrm{F}\left(27^{\circ} \mathrm{C}\right)$ to determine physical properties such as compressive strength, thickening time, rheology, free fluid, and fluid loss. The results showed that the compressive strength of the cement slurries improved significantly at 12 hours than 24 hours curing period at $87^{\circ} \mathrm{F}\left(31^{\circ} \mathrm{C}\right)$. As the concentration of fresh nano zeolite increases less time was required to reach 50 psi, 100 psi and most importantly 500 psi which is needed to resume drilling operations. An increase in concentration of fresh nano zeolite at $80^{\circ} \mathrm{F}\left(27^{\circ} \mathrm{C}\right)$ resulted in an increase in the thickening time of all the cement slurries. This shows that fresh nano zeolite has a high retardation effect. Generally, the addition of fresh nano zeolite from $1 \%$ bwoc to $3 \%$ bwoc improved the carrying capacity of all the cement slurries. Test results also showed that increasing the fresh nano zeolite concentrations resulted in a decrease in rheological values which is a characteristic of a dispersant. Plastic viscosity values were observed to have an increasing trend generally with an increasing concentration of fresh nano zeolites. All the cement slurries were below $100 \mathrm{cP}$ and therefore pumpable. The addition of fresh nano zeolite to the base cement slurry increased the free fluid of the cement slurries. The fresh nano zeolite didn't have any effect on fluid loss and therefore does not exhibit characteristics of a fluid loss agent.
\end{abstract}

Keywords: Compressive Strength, Fluid Loss, Free Fluid, Fresh Nano Zeolite, Thickening Time

\section{Introduction}

Cementing oil and gas well is a vital activity in the drilling of oil and gas drilling wells. It involves the use of cement slurry which is composed of cement powder, mixwater and performance additives or materials [1]. During primary cementing operations, a well-designed cement slurry is placed in the annulus between the wellbore and the casing to form an impermeable seal. The cement slurry bonds the casing to the formation and forms a barrier that prevents the flow of formation fluids into the wellbore. The quality of cement slurry is necessary to safely and economically produce oil over the lifetime of the well [2]. High-quality cement slurry will ensure the durability of the wellbore in long-term by providing protection for the casing $[3,4]$ whereas poor quality of cement slurry may lead to remedial cementing and will increase the time, and cost of cementing operation [5].

There are a lot of demands that are placed on cement sheath throughout the life of the well and these demands require that the physical properties of the cement slurries are enhanced with additives or materials to address the precise and unique conditions of a wellbore. There are several types of cement additives that are available in the market to allow the use of Portland cement in different oil and gas well applications [6]. Currently, over 100 additives are available for cementing oil and gas well, many of which are supplied in solid or liquid forms which include accelerators, lightweight additives, friction reducers, retarders and many more. Cementing operation is very expensive and therefore requires additives that satisfy the standard requirements and also quite different 
from conventional additives or materials. The search for alternative materials that can make cement sheath stronger, durable, flexible and cost-effective has increased.

Several authors have reported on the use of alternative additives to modify the chemical and physical properties of the oil well cement slurry in terms of flowability, stability and the long-term performance of the well. However, there is less attention on the use of zeolites as an additive which according to Ahmadi and Shekarchi [7], has excellent supplementary cementitious material. Luke et al. [8] also indicated that zeolite can be used to enhance compressive strength of cement slurries at lower temperature by its pozzolanic reaction. According to Luke et al. [8], the performance of zeolite for lightweight slurries was comparable to conventional silica fume slurries and can therefore be used as an anti-settling agent. In their research, the fluid loss was reduced with the addition of zeolite. Baig [9] evaluated the effect of nano zeolite and other conventional additives on class $\mathrm{G}$ cement slurry at high temperature and pressure. He established from the thickening time test that nano zeolite has a slight retardation effect on the setting of cement, minimal effect on density and no free water separation. From the compressive strength test using sonic method, it was observed that the addition of nano zeolite by $2 \%$ bwoc resulted in high early compressive strength.

There is still little information in open literature regarding the performance of fresh nano zeolite in oil well cement slurry at low temperature. This paper seeks to evaluate the performance of fresh nano zeolite as an additive for shallow oil well cementing operations. The outcomes of this study could help operators to ascertain the potential of fresh nano zeolites as an alternative additive in designing optimum cement slurry.

\section{Zeolite}

The term zeolite (meaning boiling stone from Greek zeo (to boil) and lithos (stone) was coined by the Swedish mineralogist Alex Fredrik Cronstedt in 1756, who discovered them and their trait of intumescence. He observed that upon heating this mineral steam was released, as water evaporated and the zeolite seemed to be boiling because of the rapid water loss [10]. Since then, zeolites were classified as a separate class of minerals. The first attempts to synthesize zeolite by imitating natural geological conditions that enabled the formation of zeolites were made by Saint Claire de Ville in 1862 . He continued the experiments until 1948, when M. R. Barrer announced that he had succeeded in obtaining a synthesized zeolite equivalent to the natural one [11]. Zeolites are microporous hydrated aluminasilicate minerals of the alkaline and alkaline earth metals that can be either natural or man-made.

All zeolites are crystalline aluminosilicates composed of a three-dimensional framework structures built of $(\mathrm{AlSi}) \mathrm{O}_{4}$ in a tetrahedron, which creates a very high Surface area [8]. They are classified according to $\mathrm{SiO}_{2}: \mathrm{Al}_{2} \mathrm{O}_{3}$ ratio [12]. Cations and water molecules are entrained into the framework. Thus, all zeolites (natural and synthetic zeolites created on the same structure as natural zeolites respectively) are composed of alumina-silicate hydrates may be represented with the Equation 1.

$$
\left.\mathrm{M}_{\mathrm{a} / \mathrm{n}}\left[\mathrm{AlO}_{2}\right)_{2}\left(\mathrm{SiO}_{2}\right)_{\mathrm{b}}\right] \cdot \mathrm{xH}_{2} \mathrm{O}
$$

Where $\mathrm{M}$ represents cations such as $\mathrm{Na}, \mathrm{K}, \mathrm{Mg}, \mathrm{Ca}$, or $\mathrm{Fe}$; and the ratio of $\mathrm{b}: \mathrm{a}$ is in a range from greater than or equal to 1 and less than or equal to 5 , $\mathrm{n}$ represents the cation valence, and $\mathrm{x}$ represents the moles of water incorporated into the zeolite structure [8]. Figure 1 shows the molecular structure of two different types of zeolite.

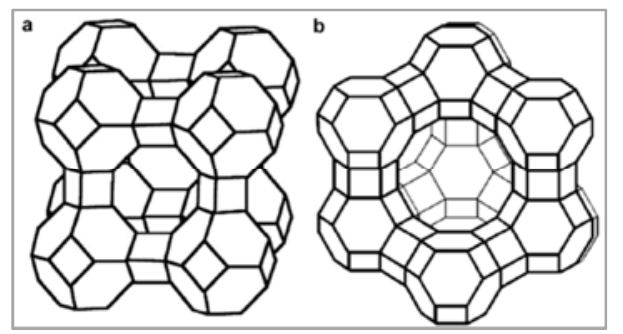

Figure 1. Molecular Structures of Two Different Types of Zeolite: (a) Zeolite A; (b) Zeolite X [13].

About 40 natural zeolites have been identified during the past 250 years, some common examples being analcime, chabazite, clinoptilolite, erionite, ferrierite, heulandite, laumontite, mordenite, and phillipsite. More than 150 zeolites have been synthesized, the most common ones being zeolites $\mathrm{A}, \mathrm{X}, \mathrm{Y}$, and ZMS-5. In most cases, it is possible to accelerate or retard the setting time by using conventional cement additives, however, special properties can be achieved by zeolites. Zeolites are known to be pozzolanic materials and may be activated with alkali or Portland cement in the presence of sufficient water. However, further properties of a zeolite-containing composition such as compressive strength development, early strength, rheology, and density, for example, are of industrial concern.

\section{Resources and Methods}

\subsection{Materials}

Cement slurries were prepared using high sulphateresistant Class $\mathrm{G}$ cement with a specific gravity of 3.14. All the cement slurries were prepared using fresh water. Fresh nano zeolite, spherically shaped with an average particle size of $100 \mathrm{~nm}$ was obtained from Tema Oil Refinery, Ghana (Figure 2). Fresh nano zeolite was mainly comprised of aluminium, carbon and silicon (Figure 3).

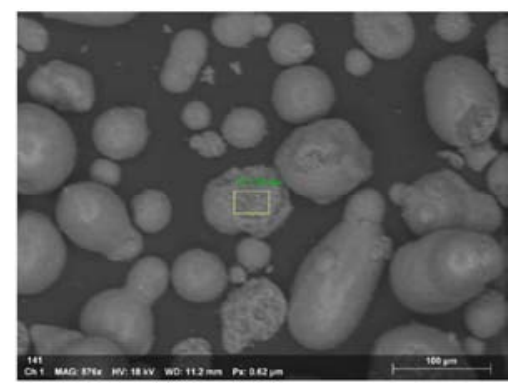

Figure 2. Scanning Electron Microscope Image for Fresh Nano Zeolite [14]. 


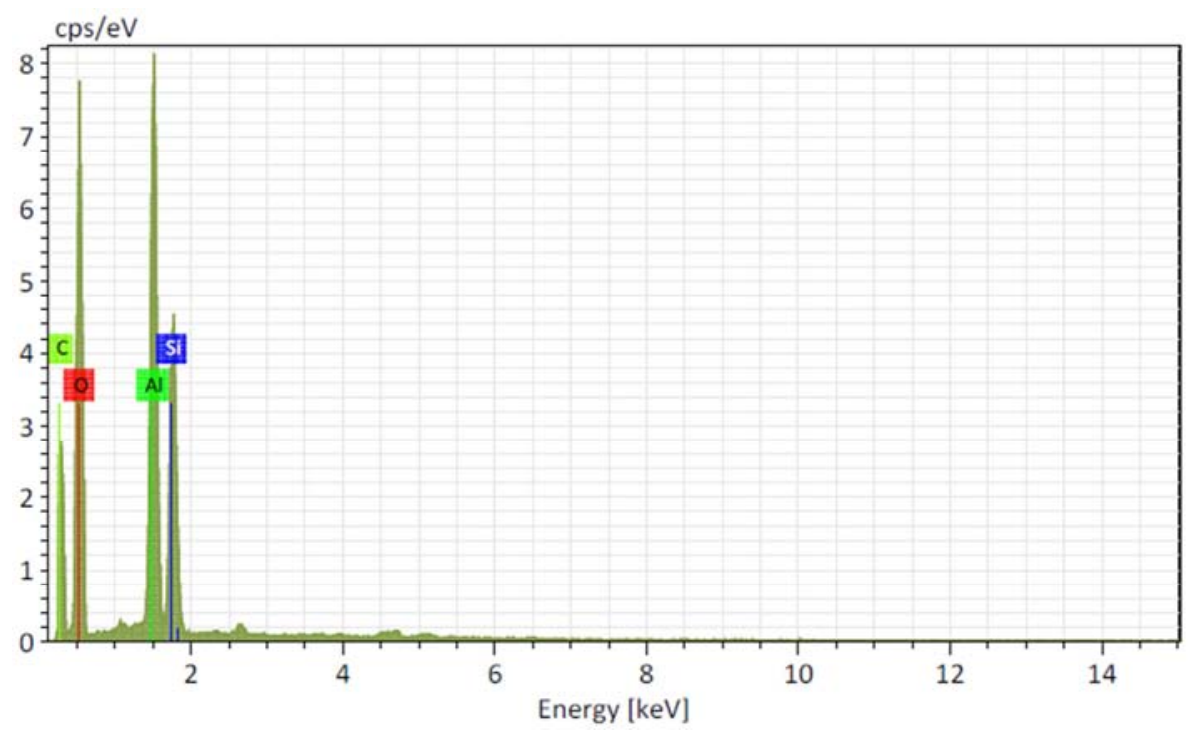

Figure 3. Energy-Dispersive X-Ray Spectroscopy Plot for Fresh Nano Zeolite [14].

\subsection{Experimental Design}

Experiments were conducted with class G cement slurry mixed with different concentrations of fresh nano zeolite at a Bottomhole Circulating Temperature (BHCT) of $80^{\circ} \mathrm{F}\left(27^{\circ} \mathrm{C}\right)$. The cement slurry was prepared by closely following API Specification 10A. Physical properties of cement such as compressive strength, thickening time, free fluid, fluid loss and rheology were determined by closely following API Specification 10A and API Recommended Practice 10B [16, 17]. The experiment was conducted using test conditions in Table 1 and the slurry composition presented in Table 2. The samples were labelled S- $0, \mathrm{~S}-1, \mathrm{~S}-2$, and S-3 depending on the concentration of the fresh nano zeolite which varied in the range of $1 \%, 2 \%$ and $3 \%$ bwoc respectively.

Table 1. Experimental Conditions.

\begin{tabular}{ll}
\hline Test Condition & Test \\
\hline BHST & $87^{\circ} \mathrm{F}\left(31^{\circ} \mathrm{C}\right)$ \\
BHCT & $80^{\circ} \mathrm{F}\left(27^{\circ} \mathrm{C}\right)$ \\
BHP & $1000 \mathrm{psi}(6.9 \mathrm{MPa})$ \\
Heat Up Time & $13 \mathrm{~min}$ \\
\hline
\end{tabular}

Table 2. Slurry Compositions.

\begin{tabular}{lllll}
\hline Slurries & Discerption & Water Cement Ratio (\%) & Type of Water & Class G Cement (\%bwoc) \\
\hline S-0 & Class G Cement & 44 & Fresh Water & 100 \\
S-1 & Class G +1\%bwoc FNZ & 44 & Fresh Water & 100 \\
S-2 & Class G + 2\%bwoc FNZ & 44 & Fresh Water & 100 \\
S-3 & Class G +3\%bwoc FNZ & 44 & Fresh Water & 100 \\
\hline
\end{tabular}

\subsection{Compressive Strength Test}

The compressive strength of a cement slurry is one of the most essential physical properties in the cementing of oil and gas wells. This property usually amounts to the determination of the strength of cement and the ability of the cement sheath to hold the induced stresses over the lifetime of the well. There are two common methods for determining the compressive strength of a cement slurry; non-destructive and destructive. The non-destructive method uses an Ultrasonic Cement Analyser (UCA) and the destructive method which is an Unconfined Compressive Strength (UCS) works by applying a load to four square inch cement cubes to determine the compressive strength of cement. In this study, the nondestructive method was used to determine the compressive strength for all the cement slurries. The UCA passes ultrasonic signals through a cement sample and measures the transit time. The transit time decrease as the cement begins to develop compressive strength. Through mathematical algorithms, the transit time is converted into an approximate value for compressive strength in pound per square inch (psi) [15]. The compressive strength test was conducted at $87^{\circ} \mathrm{F}\left(31^{\circ} \mathrm{C}\right)$ and 3 000 psi $(20.68 \mathrm{MPa})$ for 12 and 24 hours for cement slurry mixed with different concentrations of fresh nano zeolite.

\subsection{Thickening Time Test}

Thickening time is the length of time needed for the cement slurry to attain consistency of $100 \mathrm{Bc}$, at different wellbore temperature and pressure conditions. This test represents the length of time the cement slurry remains pumpable [18]. The thickening time test was conducted with a High-Pressure High-Temperature (HPHT) Consistometer that is usually rated at pressure up to $30000 \mathrm{psi}(206.8 \mathrm{MPa})$ and temperatures up to $400^{\circ} \mathrm{F}\left(204^{\circ} \mathrm{C}\right)$. The cement slurry was prepared in accordance with API procedures. The slurry was then placed in a slurry cup into a consistometer for 
testing. The testing pressure and temperature were controlled to simulate the conditions the slurry will encounter in the well. The test was concluded when the cement slurry reached a consistency of $100 \mathrm{Bc}$.

\subsection{Free Fluid Test}

Free fluid test is one of the methods that can be used to assess the stability of cement slurry. The other method is the solid settling test. Free fluid test is conducted to determine the volume of fluid that separates from a cement slurry when the cement slurry is in static condition. Excessive free fluid due to settling and water separation can cause problems such as bridging in the annulus, bridging of float equipment, lack of zonal isolation, and water pockets causing casing collapse if large temperature increases are encountered later in the life of the well. In order to measure the volume of the free fluid, the cement slurry was prepared and preconditioned in Atmospheric Consistometer for thirty (30) minutes. The preconditioned cement slurry was then poured into a $250 \mathrm{ml}$ graduated cylinder and allowed to set static for 2 hours. The cement slurry was then examined for any free fluid on top of the cement column. This free fluid was poured out of the graduated cylinder and measured to determine the percentage of free fluid using Equation (2) [16].

$$
\text { Free Fluid }=(\text { Free fluid collected } \times 100) \div 250
$$

\subsection{Rheology Test}

Rheological properties are obtained from a direct reading using a viscometer. It provides readings that are easily converted to Plastic Viscosity (PV) and Yield Point (YP). Rheology of cement slurries is critical for a proper displacement of drilling mud to ensure good cementing operations. It also has an effect on solid settling and frictional pressures [19]. The prepared slurry was conditioned at a temperature of $80^{\circ} \mathrm{F}\left(27^{\circ} \mathrm{C}\right)$ for 30 minutes using Atmospheric Consistometer. The conditioned cement slurry was poured into the viscometer cup to fill to the scribed line. The filled cup together with its table was raised until the fluid level coincided with the scribed mark on the sleeve. Direct readings in centipoise at the viscometer speed of 3, 6, 100, 200, and 300 rpm were observed and recorded. PV in centipoise (cP) and YP in pounds per 100 square feet $\left(\mathrm{lb} / 100 \mathrm{ft}^{2}\right)$ respectively were determined using Equations (3) and (4) [20].

$$
\begin{gathered}
\mathrm{PV}=1.5 \text { (300 rpm-100 } \mathrm{rpm} \text { reading) } \\
\mathrm{YP}=300 \mathrm{rpm} \text { reading-PV }
\end{gathered}
$$

\subsection{Fluid Loss Test}

Fluid loss refers to the volume of filtrate lost to the permeable material due to the process of filtration. Stirring and non-stirring fluid loss cell can be used for fluid loss measurement at desired temperature and pressure conditions. This study employed the use of the non-stirring fluid loss cell. The fluid loss test was conducted at $80^{\circ} \mathrm{F}\left(27^{\circ} \mathrm{C}\right)$ and 1000 psi (6.9 $\mathrm{MPa})$ pressure per API standards. After conditioning the slurry at the BHCT for thirty (30) minutes, the slurry was placed in the fluid cell and differential pressure of $1000 \mathrm{psi}$ (6. $9 \mathrm{MPa})$ was applied across the 325 -mesh $(45 \mu \mathrm{m})$ screen for about thirty minutes. API fluid loss was calculated using Equation 5 [16].

$$
\text { Calculated API Fluid Loss }=\frac{2 \times Q_{t} \times 5.477}{\sqrt{t}}
$$

Where, $\mathrm{Q}_{\mathrm{t}}$ is the volume ( $\mathrm{ml}(\mathrm{cc})$ ) of filtrate collected at the time $\mathrm{t}$ ( $\mathrm{min})$ of the "blowout".

\section{Results and Discussion}

\subsection{Compressive Strength Analysis}

Compressive strength analysis is critical in ascertaining the integrity and long-term bearing capacity of cement [21]. Cement with higher compressive strength usually means lower porosity and increased durability [50]. Insufficient compressive strength development may cause casings to fail, and thereby reducing the life span of the well [15]. The sample charts obtained from UCA test are presented in Figures 4-7.

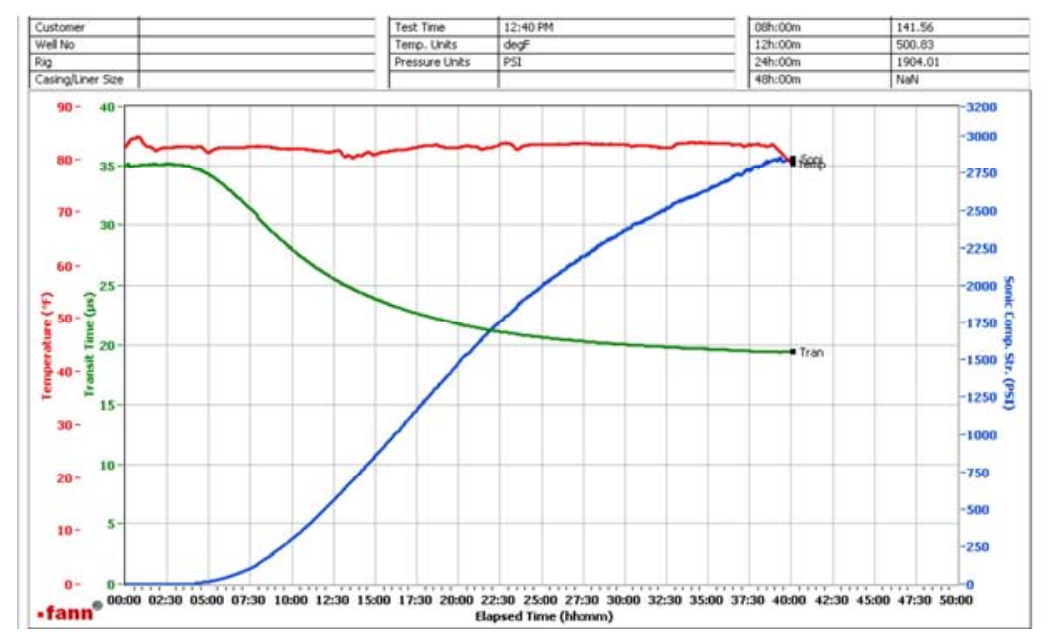

Figure 4. Compressive Strength Development for S- 0 . 


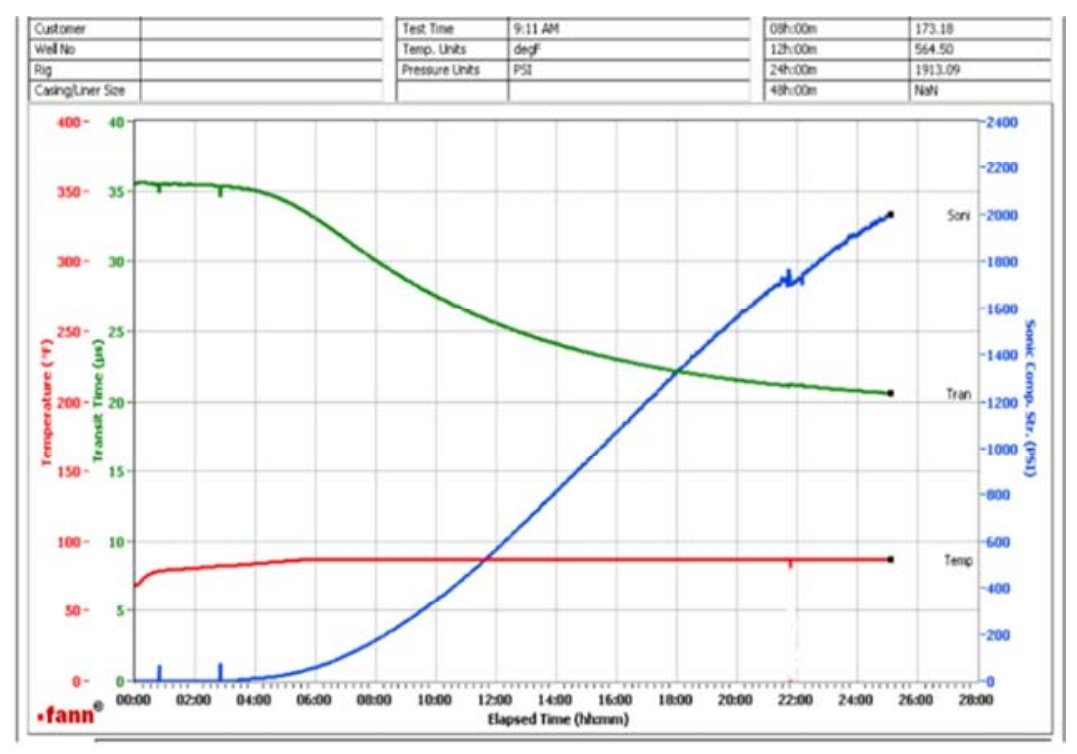

Figure 5. Compressive Strength Development for S-1.

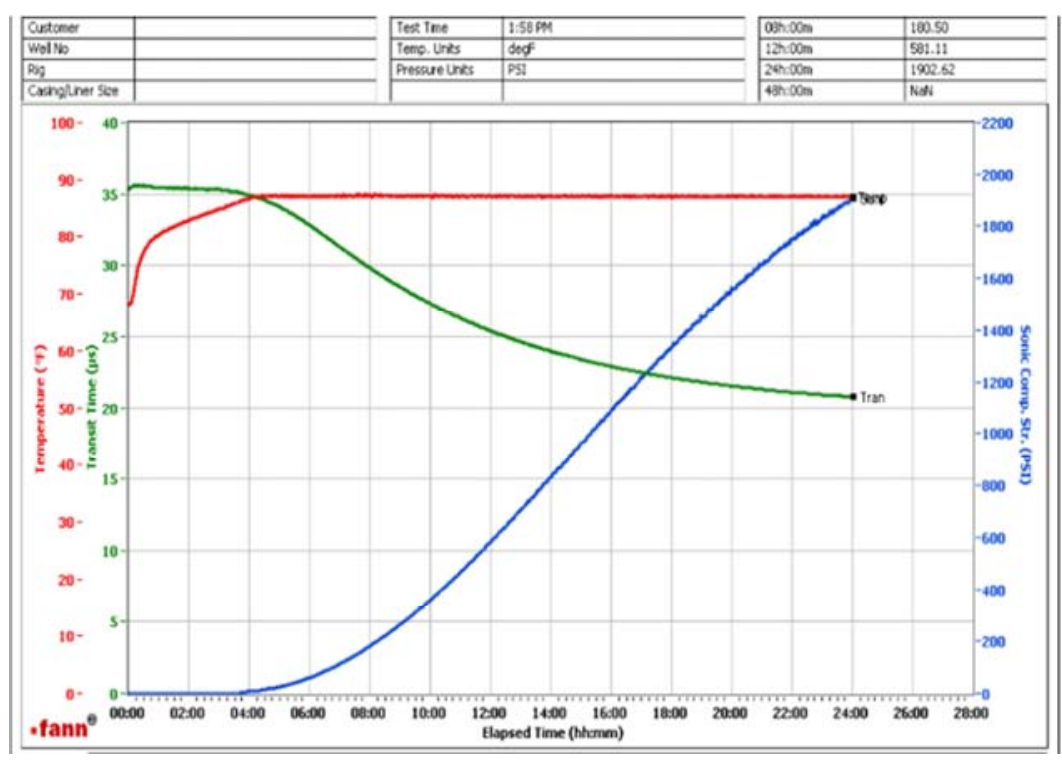

Figure 6. Compressive Strength Development for S-2.

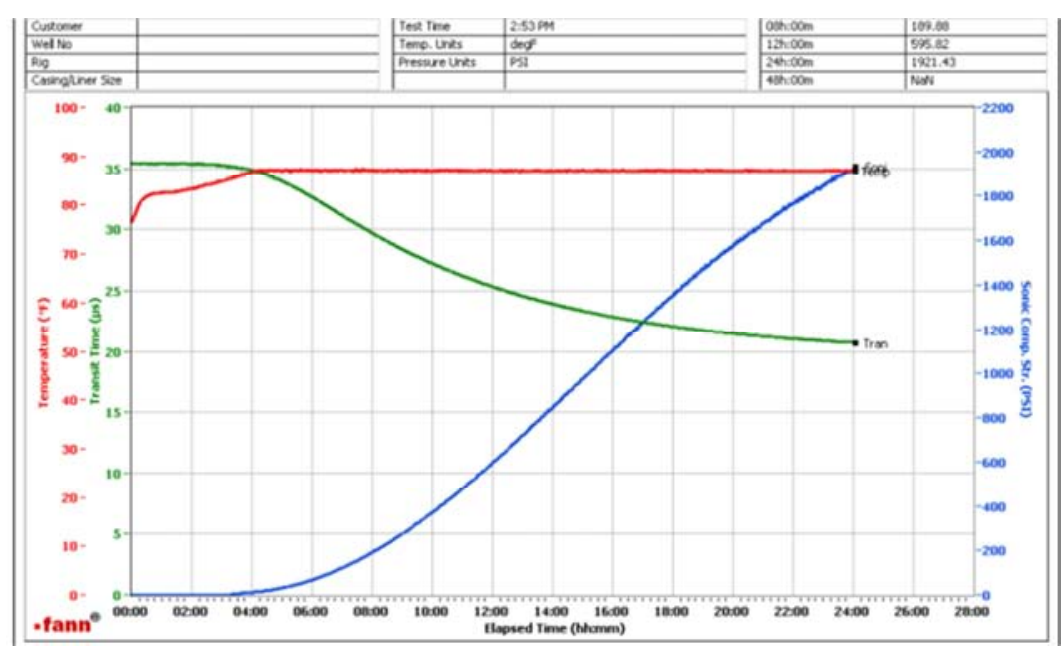

Figure 7. Compressive Strength Development for S-3. 


\subsubsection{Compressive Strength at 12 and 24 Hours}

Figure 4 shows the compressive strength for cement slurry mixed with different concentrations of fresh nano zeolite at $87^{\circ} \mathrm{F}\left(31^{\circ} \mathrm{C}\right)$ for 12 and 24 hours. From Figure 4, the compressive strength increased with increasing concentration of fresh nano zeolite by $1 \%$ bwoc and $3 \%$ bwoc at both 12 and 24 hours curing period. There is a general increase in compressive strength over the base cement slurry (S-0) for all concentrations of fresh nano zeolite. The effect of fresh nano zeolite on the compressive strength of the class $\mathrm{G}$ cement was significant at a low curing period (12 hours) as compared to high curing period ( 24 hours). At 12 hours curing period, the addition of $1 \%$ bwoc resulted in about $12 \%$ increase in compressive strength as compared to $0.5 \%$ at 24 hours curing period. Similarly, at $3 \%$ bwoc, the compressive strength increased by $19 \%$ at 12 hours compared to $0.9 \%$ at 24 hours (Figure 8)

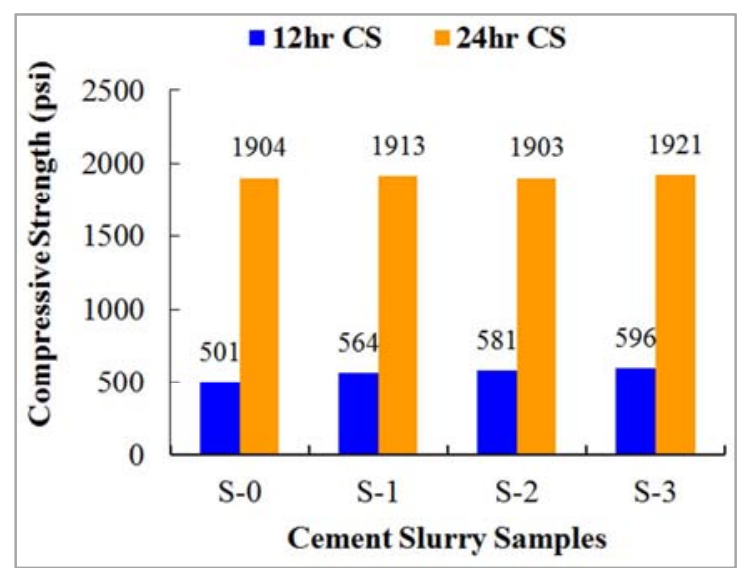

Figure 8. Compressive Strength of Cement Slurry Mixed with Different Concentration of Fresh Nano Zeolite at $87^{\circ} \mathrm{F}\left(27^{\circ} \mathrm{C}\right)$ for 12 and 24 Hours.

In general, there is no collective agreement on compressive strength requirements for oil well cement. Sze and Kadir [22] suggested that lead cement slurry should have a minimum compressive strength of 250-300 psi (1.7-2.1 $\mathrm{MPa})$ while tail cement slurry should have a minimum compressive strength of 500 psi (3.4 MPa) after for 24 hours curing period to properly hold casing. Conversely, the most widely cited minimum compressive strength needed before drilling out or support a casing is 500 psi $(3.4 \mathrm{MPa})[15,23$, 24, 25]. From Figure 8, all the slurries appeared to have enhanced compressive strength after 12 and 24 hours to structurally hold casings and early drill out. All the cement slurries had a compressive strength greater than 500 psi (3.4 $\mathrm{MPa})$. The cement slurries could not attain 2000 psi (13.8 $\mathrm{MPa})$ compressive strength after 24 hours of curing which according to Murtaza et al. [26] is the minimum compressive strength required before performing any perforation or stimulation.

\subsubsection{Time to Attain 50, 100, 500 and 1000 Psi}

Table 3 shows the time needed to attain a compressive strength of $50(0.34 \mathrm{MPa}), 100$ psi (0.69 MPa), 500 psi (3.4
$\mathrm{MPa})$ and $1000 \mathrm{psi}(6.9 \mathrm{MPa})$ for all the cement slurries. The time to reach a particular compressive strength is a vital characteristic for reducing the time to Waiting on Cement (WOC) and gas channelling through cement sheath [18]. It can be seen from Table 3 that, as the concentration of fresh nano zeolite increases less time is required to attain a compressive strength of 50 psi $(0.34 \mathrm{MPa}), 100$ psi $(0.69$ $\mathrm{MPa}$ ) and most importantly $500 \mathrm{psi}(3.4 \mathrm{MPa})$ needed to resume drilling operations. Though, there is no significant difference in the durations at low temperature $\left(87^{\circ} \mathrm{F}\right)$, a small reduction in WOC can reduce rig cost.

Table 3. Time to Attain 50, 100, 500 and 1000 psi.

\begin{tabular}{lllll}
\hline \multirow{2}{*}{ Slurry } & $\mathbf{5 0} \mathbf{~ p s i}$ & $\mathbf{1 0 0} \mathbf{p s i}$ & $\mathbf{5 0 0} \mathbf{~ p s i}$ & $\mathbf{1 0 0 0} \mathbf{~ p s i}$ \\
\cline { 2 - 5 } & (hh:mm) & (hh:mm) & (hh:mm) & (hh:mm) \\
\hline S-0 & $6: 13$ & $7: 24$ & $11: 59$ & $16: 09$ \\
S-1 & $5: 48$ & $6: 52$ & $11: 27$ & $15: 28$ \\
S-2 & 5.44 & 6.47 & 11.17 & 15.20 \\
S-3 & $5: 34$ & $6: 38$ & $11: 11$ & $15: 11$ \\
\hline
\end{tabular}

\subsubsection{Transition Period Between 50 Psi and 500 Psi}

The transition period between developing a compressive strength of $50 \mathrm{psi}(0.34 \mathrm{MPa})$ and $500 \mathrm{psi}(3.4 \mathrm{MPa})$ is very vital in cementing operation and should be as short as possible to reduce the time needed to WOC for cement slurry to harden before the next section of wellbore is drilled. Figure 9 shows the transition periods from $50 \mathrm{psi}(0.34 \mathrm{MPa})$ to 500 psi $(3.4 \mathrm{MPa})$ for all the cement slurries. It was observed that cement slurry S-2 had the shortest transition time and therefore would be very useful in reducing the time to wait on cement. S-2 recorded a transition period of 333 minutes followed by S-3 (337 mins), S-2 (339 mins) and S-0 (346 mins).

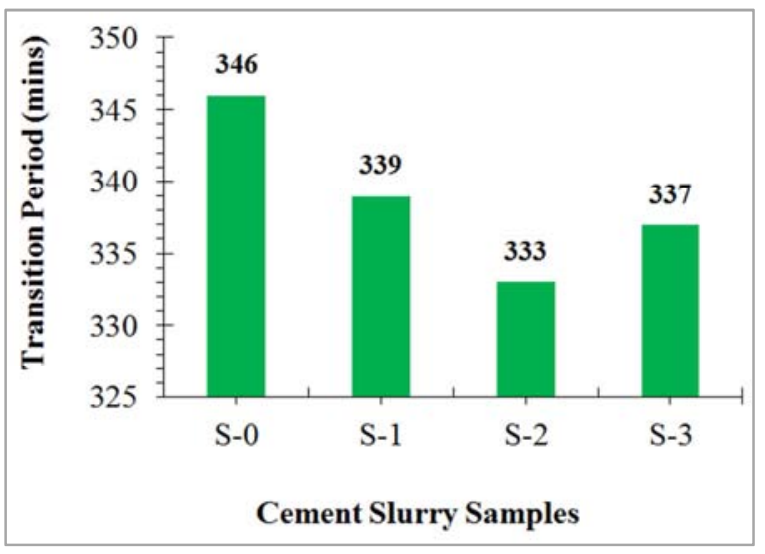

Figure 9. Transition Period from 50 psi to 500 psi at $87^{\circ} \mathrm{F}\left(27^{\circ} \mathrm{C}\right)$.

\subsection{Thickening Time Analysis}

The results of the laboratory thickening time tests provide an indication of the length of time that cement slurry would remain in a fluid state and capable of being pumped into a wellbore [27]. If a cement slurry remains liquid over a prolonged period of time and functions as a solid when it stops flowing, in a reasonable time, it will be suitable for a 
good cementing job [28]. The sample charts obtain from the thickening time test are presented in Figures 10-13. Table 4 shows the summary of the thickening time results for all the cement slurries.

Table 4. Summary of Thickening Time Test for all the Cement Slurries at $80^{\circ} \mathrm{F}$.

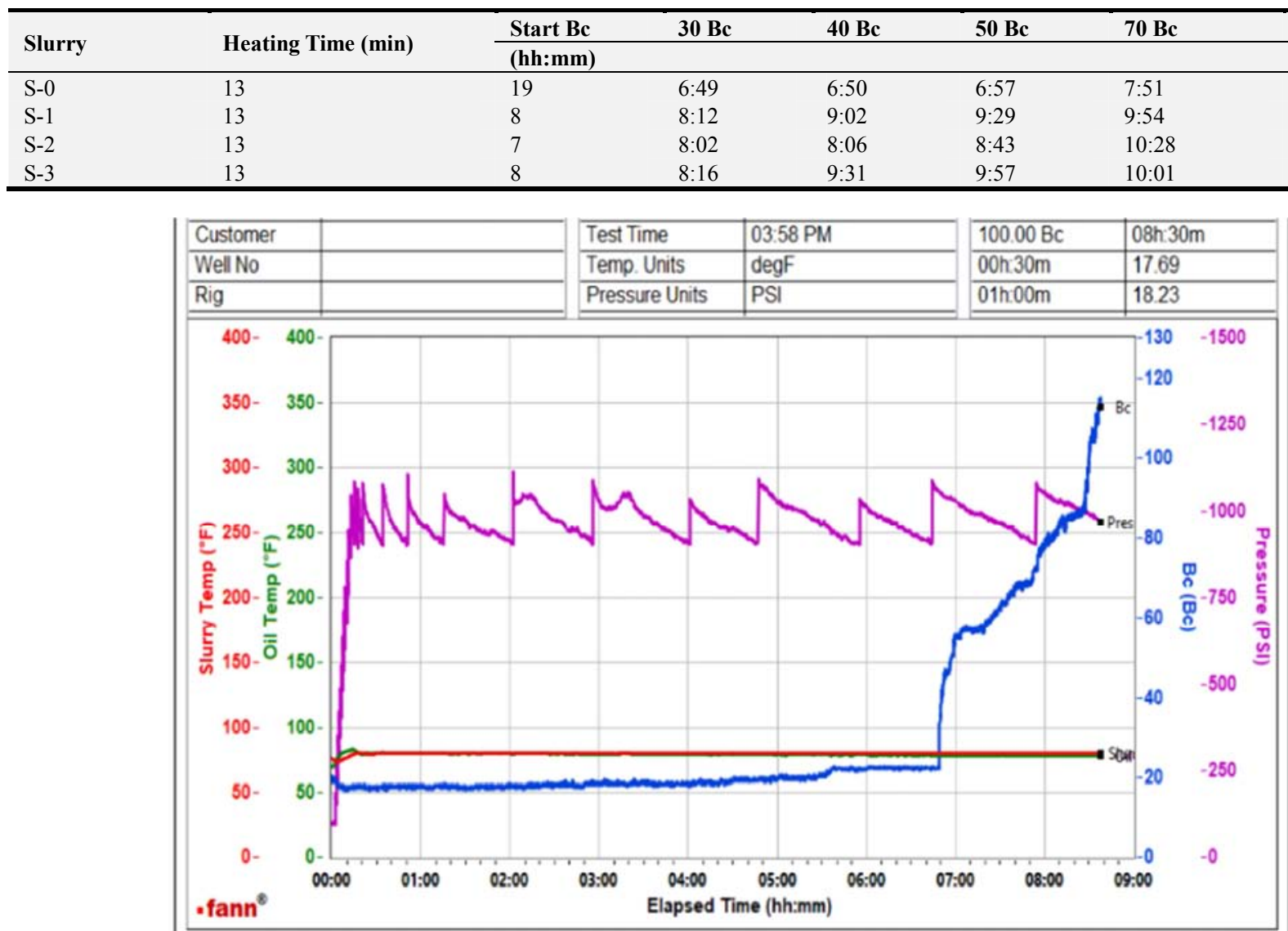

Figure 10. Thickening Time Chart for $S-0$.

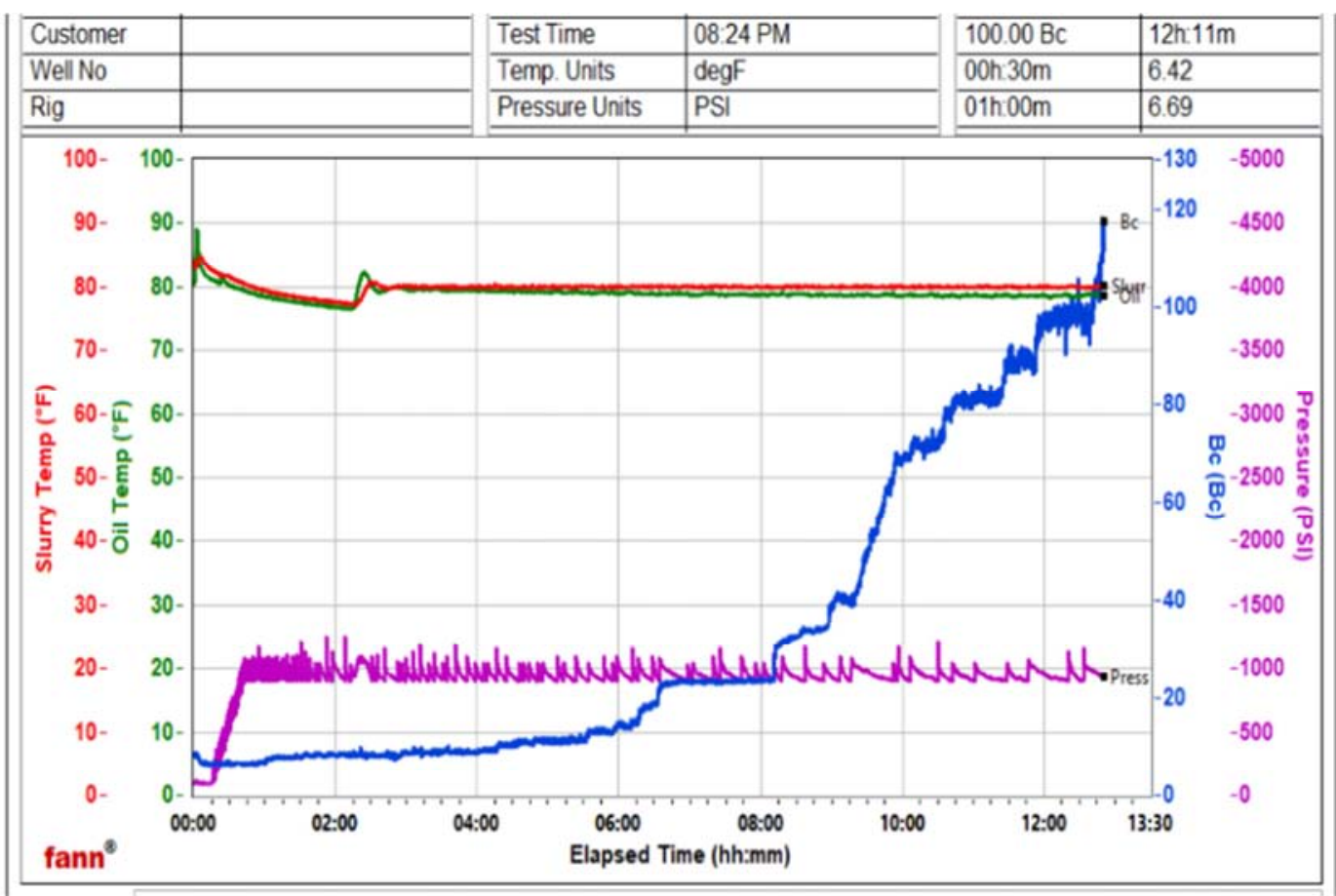

Figure 11. Thickening Time Chart for S-1. 


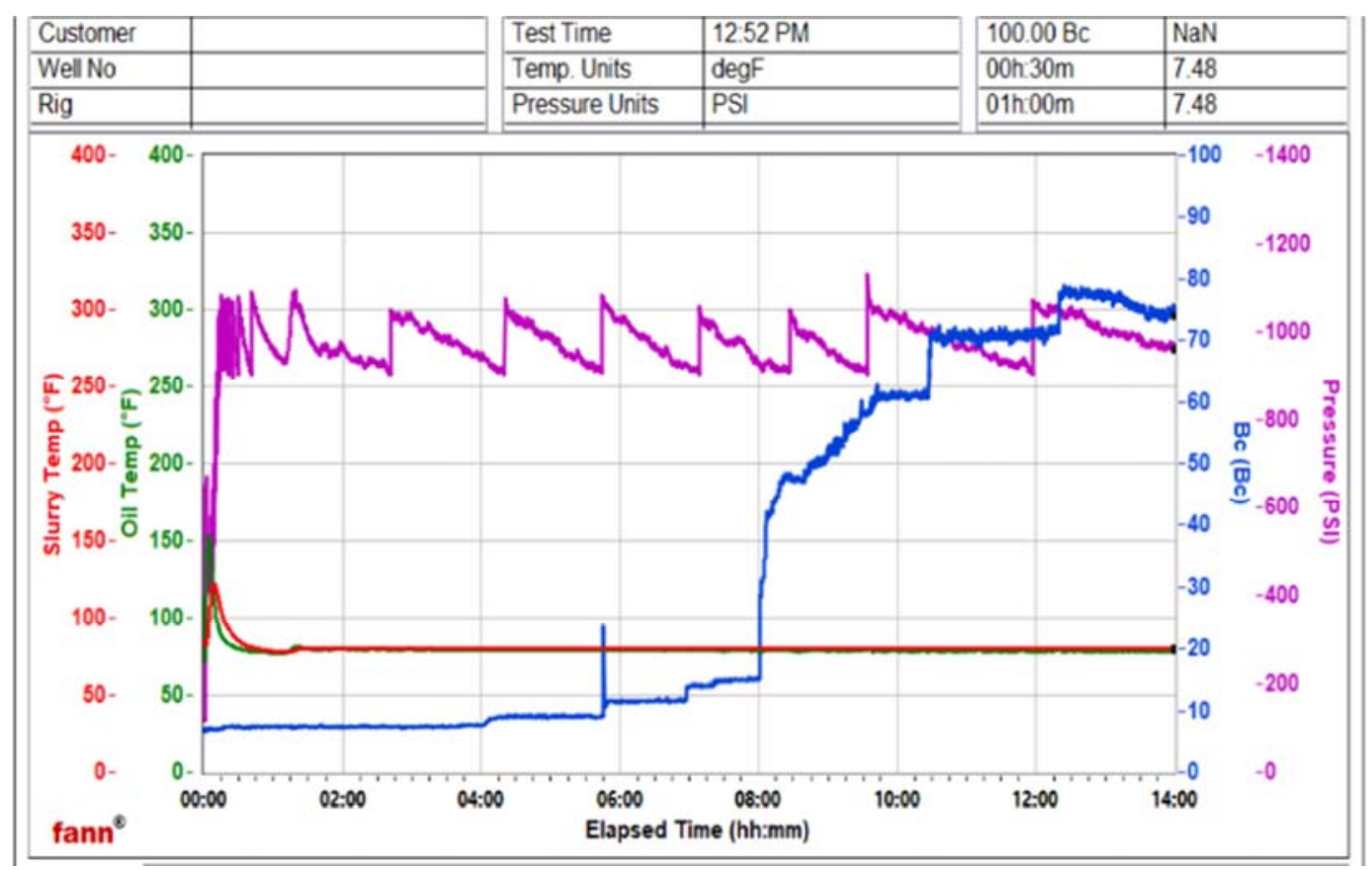

Figure 12. Thickening Time Chart for S-2.

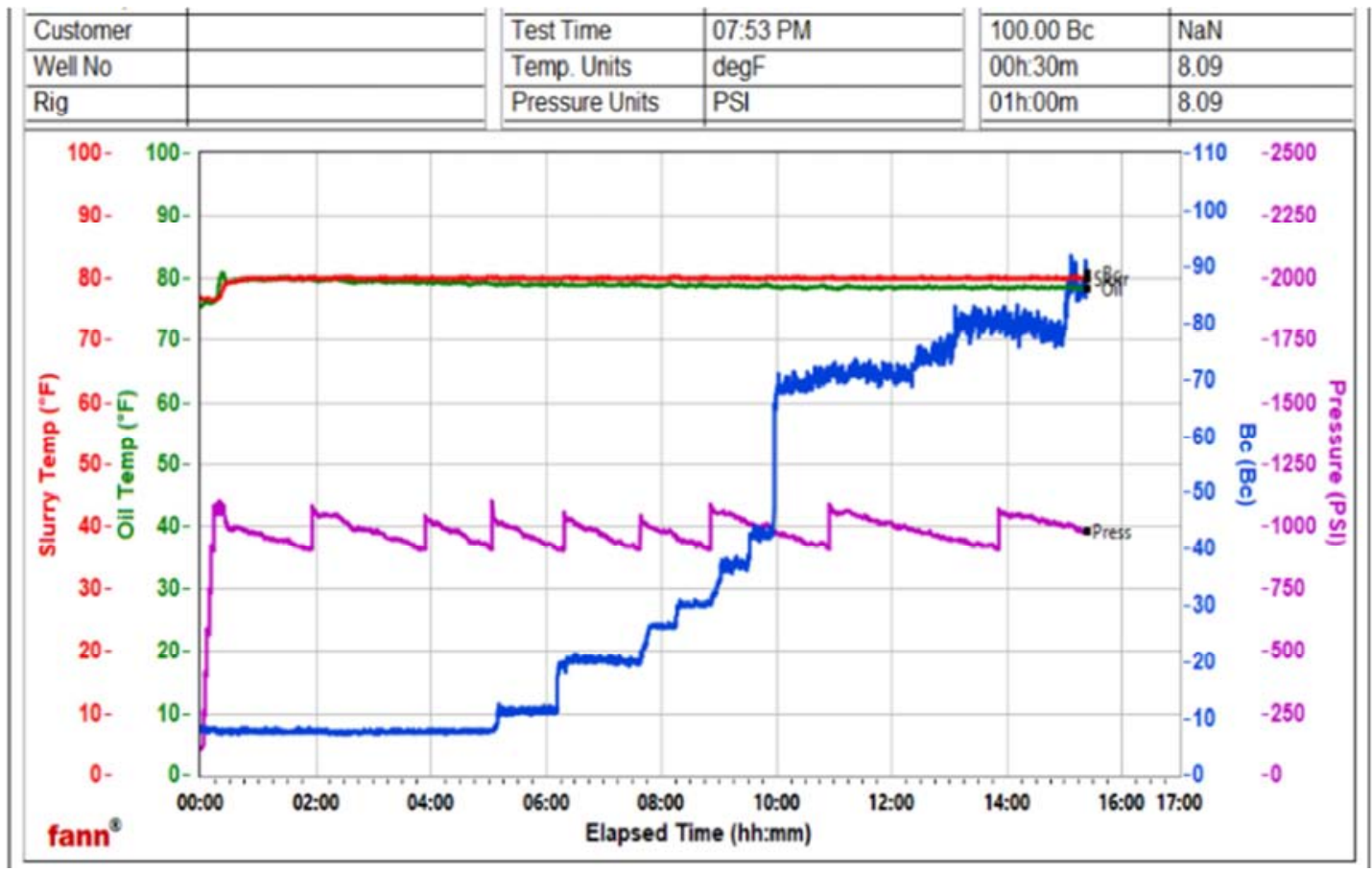

Figure 13. Thickening Time Chart for S-3.

The consistency at the start of a thickening time test indicates the viscosity at the start of the test. From Table 4, it was observed that the initial viscosity of the cement slurries decreased with an increase in fresh nano zeolite concentration compared with the base cement slurry. The initial viscosities for S-1 and S-3 did not change. There was no significant difference in the initial viscosities of all the samples mixed with fresh nano zeolite from $1 \%$ bwoc- $3 \%$ bwoc. An increase in concentration of fresh nano zeolite at $80^{\circ} \mathrm{F}\left(27^{\circ} \mathrm{C}\right)$ led to an increase in the thickening time of all the cement slurries (Table 4).
According to Broni-Bediako et al. [29], retarders are used to reduce the speed of cement hydration and therefore extending the thickening time of cement slurry. Retarders inhibit hydration and delay setting, allowing sufficient time for slurry placement in deep and hot wells [15, 23]. The trends observed from the thickening time results agree with the characteristics of retarders reported by Broni-Bediako et al. [29]. This shows that fresh nano zeolite has a high retardation effect on cement slurries and would therefore not be suitable for shallow oil well cementing operations as 
operators will have to wait on cement for long period before the cement set and harden. The end of the thickening time test was considered to be 70 Bearden units of consistency $(\mathrm{Bc})$ which is considered as the point where cement slurry set and becomes unpumpable [27, 30]. At $70 \mathrm{Bc}$, it was observed that there was about 2 hours 3 minutes increase in thickening time at $1 \%$ bwoc (S-1) compared with the base cement slurry (S$0)$.

\subsection{Rheological Analysis}

Rheology of cement is a controlling factor that ensures the performance of cement and assists in measuring the pumpability of cement slurry [26]. In this study, rheological properties such as plastic viscosity and yield point of cement slurries were determined. Table 5 presents the rheological properties of cement slurries mixed with different concentrations of fresh nano zeolite at a temperature of $80^{\circ} \mathrm{F}$ $\left(27^{\circ} \mathrm{C}\right)$.

Table 5. Rheological Properties of Cement Slurries Mixed with Different Concentrations of Fresh Nano Zeolite at $80^{\circ} \mathrm{F}\left(27^{\circ} \mathrm{C}\right)$.

\begin{tabular}{|c|c|c|c|c|}
\hline \multirow{2}{*}{ Test Parameters } & S-0 & S-1 & S-2 & S-3 \\
\hline & \multicolumn{4}{|c|}{ Dial Readings in Centipoise (cP) } \\
\hline $600 \mathrm{rpm}$ & 119 & 117 & 117 & 115 \\
\hline $300 \mathrm{rpm}$ & 81 & 75 & 71 & 72 \\
\hline $200 \mathrm{rpm}$ & 69 & 63 & 52 & 50 \\
\hline $100 \mathrm{rpm}$ & 55 & 49 & 39 & 40 \\
\hline $6 \mathrm{rpm}$ & 21 & 19 & 15 & 15 \\
\hline $3 \mathrm{rpm}$ & 15 & 14 & 11 & 11 \\
\hline$P V(c P)$ & 39 & 39 & 48 & 48 \\
\hline$Y P\left(l b . / 100 f t^{2}\right)$ & 42 & 36 & 23 & 24 \\
\hline$P V / Y P$ & 0.93 & 1.1 & 2.1 & 2 \\
\hline
\end{tabular}

\subsubsection{PV and YP}

From Table 5, plastic viscosity is observed to have an increasing trend generally with an increasing concentration of fresh nano zeolites. The addition of $1 \%$ bwoc of fresh nano zeolite did not increase the PV of the base cement slurry or sample. An increase in PV was observed at $2 \%$ bwoc and $3 \%$ bwoc. PV controls the pumpability of cement slurries. Generally, the problem of pumping cement slurry through wellbore occurs when PV becomes high. That is, cement slurries with PV above $100 \mathrm{cP}$ will require high pressure to pump and place in the annulus [18, 19]. All the cement slurries were below $100 \mathrm{cP}$ and therefore pumpable (Table 5).

The YP on the other hand was influenced by the addition of fresh nano zeolite. YP is defined as the initial resistance to flow caused by electrochemical forces between the particles and it indicates the amount of force needed to initiate flow. It also controls the carrying capacity of the cement slurry [31]. From Table 5, the yield point decreased with increasing concentration of fresh nano zeolite. The lower the YP values, the thinner the cement slurry and the tendency for it to settle. The YP values calculated also revealed that all the cement slurries were pumpable at $80^{\circ} \mathrm{F}\left(27^{\circ} \mathrm{C}\right)$ as all the yield point values were above $15 \mathrm{lb} / 100 \mathrm{ft}^{2}$ recommended by Salehi and Paiaman [32].

\subsubsection{Shear Stress and Shear Rate Curve}

Figure 14 indicates the shear stress and shear rate curves for base cement slurry mixed with different concentrations of fresh nano zeolite. It was observed that the addition of fresh nano zeolite in cement slurries reduced the shear stresses for all given shear rates as compared to the base cement slurry. The rheological values for fresh nano zeolite concentration of $2 \%$ bwoc and $3 \%$ bwoc appeared to have no significant difference. Generally, additives with retarding characteristics exhibit decreasing rheological values as the concentration of the additives are increased. Test results showed that increasing the concentration of fresh nano zeolite resulted in a decrease in rheological values. This shows that as well as affecting the thickening time, it also exhibited dispersing tendencies.

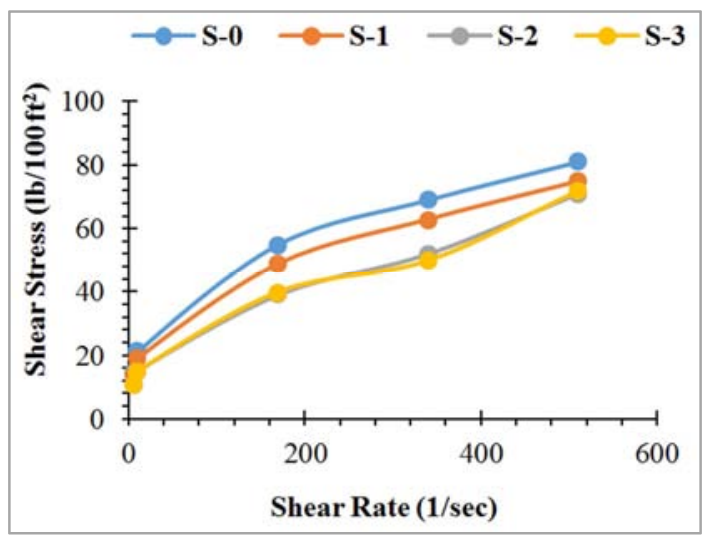

Figure 14. Shear Stress and Shear Rate Curve for Different Concentrations of Fresh Nano Zeolite-Based Cement Slurries at $80^{\circ} \mathrm{F}\left(27^{\circ} \mathrm{C}\right)$.

\subsubsection{PV/YP Ratio}

Figure 15 shows the $\mathrm{PV} / \mathrm{YP}$ ratios of all the cement slurries. According to Magzoub et al. [33] and Luo et al. [34], $\mathrm{PV} / \mathrm{YP}$ describes the carrying capacity of drilling fluids. Generally, any value of the ratio of $\mathrm{YP} / \mathrm{PV} \geq 0.75$ or $\mathrm{PV} / \mathrm{YP} \geq$ 1.3 shows a good carrying capacity of a drilling fluid and can therefore lead to an improved cleaning of the wellbore. In this study, the ratio $\mathrm{PV} / \mathrm{YP}$ was introduced to determine the carrying capacity of the cement slurries. The cement slurry with good carrying capacity prevents settling of cement particles and results in homogeneous placement around casings without providing a sag effect. Heterogeneous placement with varying density profiles along the length of cement column can lead to many wellbore issues such as fluid migration, free fluid separation and fracturing. The recommended safe window for the carrying capacity of cement slurries lie in the range of 1 to 2 ratio [35]. A PV/YP ratio above 2 reduces the carrying capacity of cement slurries and has the ability to cause settling or sagging problems in the wellbore. A reduction in PV/YP ratio number on the other hand causes an increase in carrying capacity. If the ratio of a cement slurry falls below 1 , then the slurry will require a high pumping force to pump down into the wellbore. This could cause an increase in the Equivalent Circulating Density (ECD) by giving high friction and thereby causing lost 
circulation due to formation fracturing [26].

From Figure 15, it could be noticed that the base cement slurry had low PV/YP ratio which is an indication that high force will be required to pump the base cement slurry into the wellbore, though the value is close to the safety region. The addition of $1 \%$ bwoc and $3 \%$ bwoc of fresh nano zeolite to the base cement slurry increased the PV/YP ratio from 0.9 to 1.1 and 2.0 respectively. These values were within the acceptable region and thus increased the carrying capacity of the base cement slurry. The addition of $2 \%$ bwoc of fresh nano zeolite resulted in PV/YP ratio of 2.1 which is slightly above the acceptable region. Generally, the addition of fresh nano zeolite from $1 \%$ bwoc to $3 \%$ bwoc to the base sample or cement slurry increased the PV/YP ratio of all the cement slurries.

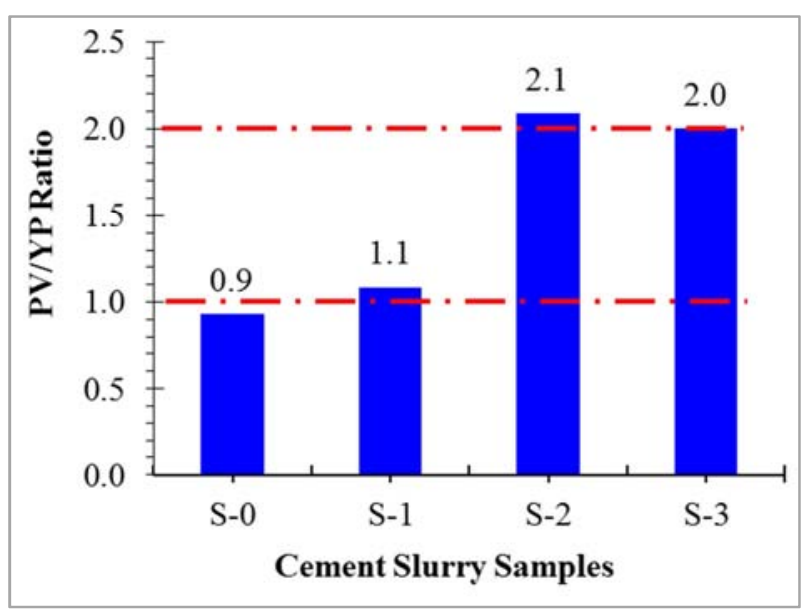

Figure 15. PV/YP Ratio for Different Concentrations of Fresh Nano Zeolite at $80^{\circ} \mathrm{F}\left(27^{\circ} \mathrm{C}\right)$.

\subsection{Free Fluid Analysis}

When cement is setting, free fluid separates from the cement slurry and settles on top of the cement column or in small water pockets if the well deviates. This free fluid can create channels while moving on the top of cement and cause a poor cement bond or casing failure if the water pockets are between the annulus of two casings [20]. Hence, free fluid is expected to be as low as possible and if necessary, almost close to zero for an ideal cementing operation to prevent water channelling and casing failures. The results of free fluid of all the cement slurries at $80^{\circ} \mathrm{F}\left(27^{\circ} \mathrm{C}\right)$ is presented in Table 6.

Table 6. Free Fluid at $80^{\circ} \mathrm{F}\left(27^{\circ} \mathrm{C}\right)$.

\begin{tabular}{lll}
\hline Slurry & Measured Volume $(\mathrm{ml})$ & \% Free Fluid \\
\hline S-0 & 1.6 & 0.64 \\
S-1 & 3.6 & 1.44 \\
S-2 & 2.6 & 1.04 \\
S-3 & 2 & 0.8 \\
\hline
\end{tabular}

Table 6 above shows that at $1 \%$ bwoc (S-1), the percentage of free fluid recorded was $1.44 \%$. However, increasing the concentration of fresh nano zeolite by $2 \%$ and $3 \%$ (S-2 and S-3) resulted in a decreasing trend. In general, the addition of fresh nano zeolite from $1 \%$ bwoc to $3 \%$ bwoc to the base cement slurry led to an increase in the free fluid of the cement slurries.

\subsection{Fluid Loss Analysis}

Table 7, clearly indicates that high volumes of filtrates were lost with the introduction of fresh nano zeolite in the base cement slurry. These high losses in the filtrate were observed under few seconds of subjecting the slurry to the test. This suggests that fresh nano zeolite does not exhibit the characteristics of a fluid loss agent or additive.

Table 7. Fluid Loss at $80^{\circ} \mathrm{F}\left(27^{\circ} \mathrm{C}\right)$.

\begin{tabular}{llll}
\hline Slurry & $\begin{array}{l}\text { Measured Volume } \\
(\mathbf{m l})\end{array}$ & $\begin{array}{l}\text { Test Time } \\
(\mathbf{s e c s})\end{array}$ & $\begin{array}{l}\text { Calculated Fluid } \\
\text { Loss }\end{array}$ \\
\hline S-0 & 50 & 20 & 949 \\
S-1 & 51 & 40 & 684 \\
S-2 & - & - & - \\
S-3 & - & - & - \\
\hline
\end{tabular}

\section{Conclusions and Recommendation}

From the study, it could be concluded that:

i. The effect of fresh nano zeolite on compressive strength of class $G$ cement slurry appeared to be significant at low curing period (12 hours) as compared to high curing period ( 24 hours) at $87^{\circ} \mathrm{F}$ $\left(27^{\circ} \mathrm{C}\right)$.

ii. As the concentration of fresh nano zeolite increases less time was required to reach $50 \mathrm{psi}(0.34 \mathrm{MPa}), 100$ psi $(0.69 \mathrm{MPa})$, and most importantly 500 psi $(3.4$ $\mathrm{MPa}$ ) which is needed to resume drilling operations.

iii. An increase in the concentration of fresh nano zeolite at $80^{\circ} \mathrm{F}$ led to an increase in the thickening time of all the cement slurries. This shows that fresh nano zeolite has a high retardation effect on cement slurries.

iv. Generally, the addition of fresh nano zeolite at $1 \%$ bwoc and $3 \%$ bwoc to the base cement slurry improved the carrying capacity of the base cement slurry with the exception of $2 \%$ bwoc.

v. Test results indicated that, increasing the concentration of fresh nano zeolite caused a decrease in rheological values which is a characteristic of a dispersant.

vi. Plastic viscosity was observed to have an increasing trend generally with increasing concentration of fresh nano zeolites. All the cement slurries were below 100 $\mathrm{cP}$ and therefore pumpable.

vii. The fresh nano zeolite didn't have any effect on fluid loss. It does not exhibit the characteristics of a fluid loss agent.

viii. Generally, the addition of fresh nano zeolite from $1 \%$ bwoc to $3 \%$ bwoc to the base cement slurry increased the free fluid of the cement slurries.

From the conclusion drawn from the study, it is recommended that further work be done on the combined effects of fresh nano zeolites and conventional additives on oil well cement slurries at low temperatures. 


\section{References}

[1] Hodne, H. (2007), "Rheological Performance of Cementitious Materials used in Well Cementing", PhD Thesis, University of Stavanger, Stavanger, Norway, $8 \mathrm{p}$.

[2] Ridha, S., Irawan, S., Ariwahjoedi, B. and Jasamai, M. (2010), "Conductivity Dispersion Characteristic of Oilwell Cement Slurry during Early Hydration", International Journal of Engineering and Technology, Vol. 10, No. 6, pp. 121-124.

[3] Ershadi, V., Ebadi, T., Rabani, A. R., Ershadi, L. and Soltanian, H. (2011), "Reduction of Set Cement Permeability in Oil Well to Decrease the Pollution of Receptive Environment using Spherical Nanosilica, 2nd International Conference on Environmental Science and Technology, IPCBEE, Singapore, Vol. 6, pp. 101-104.

[4] Pourafshary, P., Azimipour, S. S., Motamedi, P., Samet, M., Taheri, S. A. and Bargozin, H. P. (2009), "Priority Assessment of Investment in Development of Nanotechnology in Upstream Petroleum Industry" Society of Petroleum Engineers Saudia Arabia Section Technical Symposium, SPE 126101, AlKhobar, Saudi Arabia, pp. 1-11.

[5] Nelson, E. B., Baret, J. F. and Michaux, M. (1990), "Cement Additives and Mechanism of Action”, In Well Cementing, E. B. Nelson (Ed.), Elsevier Science Publishers, Amsterdam, pp. 3-37.

[6] Boni-Bediako, E., Joel, O. F. and Ofori-Sarpong, G. (2016), "Oil Well Cement Additives: A Review of the Common Types", Oil and Gas Research, Vol. 2, No. 1, pp. 1-7.

[7] Ahmadi, B. and Shekarchi, M. (2010), "Use of Natural Zeolite as a Supplementary Cementitious Material", Cement and Concrete Composites, Vol. 32, No. 2, pp. 134-141.

[8] Luke, K., Reddy, B. R, Fitzgerald, R. M., Zamora, F., Fyten, G. C, Rispler, K. A, Getzlaf, D. A, Gray, D. W. and Dealy, S. T. (2004), "Zeolite Containing Cement Composition", US Patent Application Publication, No. 0112600 2, 39 pp.

[9] Baig, M. T. (2017), "Evaluation of Nano Zeolite as an Additive for Oil-Well Cementing", Unpublished MSc Thesis, King Fahd University of Petroleum and Minerals, Dhahran, Saudi Arabia, 143 pp.

[10] Byrappa, K. and Yoshimura, M. (2001), "Hydrothermal Technology Principles and Applications", Handbook of Hydrothermal Technology, pp. 1-52.

[11] Tsitsishvili, G. V., Skhirtladze, N. S., Andronikashvili, T. G., Tsitsishvili, V. G. and Dolidze, A. V. (1999), "Natural Zeolites of Georgia: Occurrences, Properties, and aAplication", Studies in Surface Science and Catalysis, Vol. 125, pp. 715-722.

[12] Nagrockiene, D. and Girskas, G. (2016), "Research into the Properties of Concrete Modified with Natural Zeolite Addition", Construction and Building Materials, Vol. 113, pp. 964-969.

[13] Caputo, D., Liguori, B. and Colella, C. (2008), "Some Advances in Understanding the Pozzolanic Activity of Zeolites: The Effect of Zeolite Structure", Cement and Concrete Composites, Vol. 30, No. 5, pp. 455-462.

[14] Amarfio, E. M. (2020), "Effect of $\mathrm{Al}_{2} \mathrm{O}_{3}$ Nanoparticles, Fresh and Equilibrium Zeolite, on the Rheological Behaviour of WBM Systems at the High Temperature", PhD Seminar Presentation, University of Mines and Technology, Tarkwa, Ghana, 30 pp.

[15] Huwel, J. P. E., Faustino, V. and Roberts, R. (2014), “Cement Compressive Strength Development Drastically Affected by Testing Procedure", Proceedings of American Association of Drilling Engineers Fluid Conference and Exhibition, pp. 1-5.

[16] Anon (1997), American Petroleum Institute (API) Recommended Practice 10B for Testing Well Cements, American Petroleum Institute, Washington D. C., USA, 134 pp.

[17] Anon (2013), American National Standard Institute/American Petroleum Institute (ANSI/API) Specification 10A for Cements and Materials for Well Cementing, API Publication Services, Washington D. C., 38 pp.

[18] Abbas, G. Irawan, S. Kumar, S. Memon, R. K. and Khalwar, S. A. (2014), "Characteristics of Oil Well Cement Slurry using Hydroxypropylmethylcellulose", Journal of Applied Sciences, 14: pp. 1154-1160.

[19] Broni-Bediako, E. Ofori-Sarpong, G. and Joel. O. F. (2015), Comparative Study of Local Cements with Imported Class ' $G$ ' Cement at Different Temperatures of Oil Well Cementing Operations in Ghana, Journal of Petroleum and Environmental Biotechnology, Vol. 6, No. 4, pp. 1-7.

[20] Broni-Bediako, E. and Amorin, R. (2018), "Enhancing the Performance of Local Cement as an Alternative for Oil and Gas Well Cementing Operation", Petroleum and Coal, Vol. 60, No. 5, pp. 977-984.

[21] De Andrade, J. and Sangesland, S. (2016), "Cement Sheath Failure Mechanisms: Numerical Estimates to Design for Long-term Well Integrity", Journal of Petroleum Science and Engineering, Vol. 147, pp. 682-698.

[22] Sze, W. H. and Kadir, A. A. (2011), "The Potential of Lawin Tuff for Generating a Portland Fly Ash Cement to be used in Oil Well Cementing", International Journal of Engineering and Technology, Vol. 11, pp. 51-55.

[23] Kutasov, I. M. and Eppelbaum, L. V. (2014), "Temperature Regime of Boreholes: Cementing of Production Liners", Proceedings of the 2014 Stanford Geothermal Workshop, pp. 1-5.

[24] Shuker, M. T, Memon, K. R., Tunio, S. Q. and Memon, M. K. (2014), "Laboratory Investigation on Performance of Cement Using Different Additives Schemes to Improve Early Age Compressive Strength", Research Journal of Applied Sciences, Engineering and Technology, Vol. 7 (11), pp. 2298-2305.

[25] Murtaza, M., Mahmoud, M. and Tariq, Z. (2020), "Experimental Investigation of a Novel, Efficient, and Sustainable Hybrid Silicate System in Oil and Gas Well Cementing", Energy and Fuels, Vol. 34, No. 6, pp. 7388-7396.

[26] Labibzadeh, M., Zahabizadeh, B. and Khajehdezfuly, A. (2010), "Early-age Compressive Strength Assessment of Oil well Class $\mathrm{G}$ Cement due to Borehole Pressure and Temperature Changes", Journal of American Science, Vol. 6, No. 7, pp. 38-47.

[27] Alp, B. and Akin, S. (2013), "Utilization of Supplementary Cementitious materials in geothermal Well Cementing", Proceedings of Thirty-Eighth Workshop on Geothermal Reservoir Engineering, pp. 1-7. 
[28] Roshan, H. and Asef, M. R. (2010), "Characteristics of Oilwell Cement Slurry using CMC", Drilling and Completion, Vol. 25, No. 3, pp. 328-335.

[29] Broni-Bediako, E., Joel, O. F. and Ofori-Sarpong, G. (2016), "Oil Well Cement Additives: A Review of the Common Types", Oil and Gas Research, Vol. 2, No. 1, pp. 1-7.

[30] Bett, E. K. (2010), "Geothermal Well Cementing, Materials and Placement Techniques", Geothermal Training Programme Report, No. 10, pp. 99-130.

[31] Azar, J. J. and Samuel, G. R. (2007), "Drilling Engineering", PennWell Corporation, Tulsa, OK, USA, 438 pp.

[32] Salehi, R. and Paiaman, A. M. (2009), "A Novel Cement Slurry Design Applicable to Horizontal Well Conditions", Petroleum and Coal; Vol. 51, No. 4, pp. 270-276.
[33] Magzoub, M., Mahmoud, M., Nasser, M., Hussein, I., Elkatatny, S. and Sultan, A. (2019), "Thermochemical Upgrading of Calcium Bentonite for Drilling Fluid Applications", Journal of Energy Resources Technology, Vol. 141, No. 4. pp. 1-25.

[34] Luo, J., Zhang, C., Duan, Z., Wang, B., Li, Q., Chung, K. L., Zhang, J. and Chen, S. (2018), "Influences of Multi-walled Carbon Nanotube (MCNT) Fraction, Moisture, Stress/Strain Level on the Electrical Properties of MCNT Cement-based Composites", Sensors and Actuators A: Physical, Vol. 280, pp. 413-421.

[35] Elkatatny, S., Gajbhiye, R., Ahmed, A. and Mahmoud, A. A. (2020), "Enhancing the Cement Quality using Polypropylene Fiber", Journal of Petroleum Exploration and Production Technology, Vol. 10, No. 3, pp. 1097-1107. 